\title{
Challenges of Agriculturists in Coconut Cultivation of Meenakshipuram Village, Chittur Taluk, Kerala
}

\author{
K.Veerakumar
}

\begin{abstract}
Coconut cultivation is a landmark of kerala. In this paper, an attempt has been made to find agriculturist level of challenge towards Coconut cultivation. A sample of 100 respondent's were purposively selected from Meenakshipuram Village, Chittur Taluk, Kerala. The findings were analyzed using simple percentage analysis, chi-square test and friedman ranking test. Findings reveal that major challenge faced by the agriculturist towards coconut cultivation is unstable price in the market. The research concluded that government should organize coconut cultivation related challenge programme to agriculturist.
\end{abstract}

Keywords: Agriculturist, Coconut cultivation, Government, Uses, Problems, Varieties

\section{INTRODUCTION}

Agriculture is actually a base of the Indian overall economy. If horticulture output boosts overall monetary indication will go upwards. After and before independence that remains the biggest economic sector in the United States and has a substantial position in the entire primary sectors' socio financial advancement of India. Coconut creation in Kerala takes on an essential purpose in the condition economy and lifestyle of Kerala in southwestern India. Kerala is in fact named following the coconut pine with "Kerala" signifying Coconut tree and "Alam" signifying and therefore means very well Property of "Coconut Trees". Several conditions like Copra and Coir derive from the native Malayalam vocabulary.

By late 1972s it paid for a few $68 \%$ of total creation found in India including one level some 899, 198 hectares had been apparently under nurturing. Today Kerala creates approximately $45 \%$ of India's coconuts, with some $92 \%$ of total creation lying down in the southern part of Indian claims and Kerala's neighbors. The Coconut Expansion Plank which will plays a significant role inside the advancement of coconut creation in India provides it has the headquarters found in Kochi, Kerala.

Even many trendy articles at the needed time have been published authored by Dr.K.Veerakumar, articled titled "Challenges of Agriculturists in Coconut Cultivation of Meenakshipuram Village, Chittur Taluk, Kerala" was published with fullest support of family members and agriculturists around who are basically educated very low. This is particular to be published in reputed international journal even after many struggles to make whole world to turn towards a tiny beautiful village in Meenakshipuram, called Karupputhuraikadu, and leave a mark in Google plat form to record a place, Government has to support agriculturists and support for further development of village, is motive of this article publication rather than academic concerned of author. The personalities are to be turned back as modern agriculturist at least from this generation. This article is dedicated to those who respect "Agriculturists".

\section{SOME OF THE VARIETIES OF COCONUT}

\section{$>$ KalpaRaksha}

That is a partial tall range with nice tender nut drinking water and with larger level of resistance to root (wiIt) disease of coconut. This involves blooming by fifty four weeks coming from planting. lts annual produce is usually 87 nuts/palm, sixteen. 38 kilogram copra/palm and 10. sixtyfive $\mathrm{kg}$ essential oil /palm. Found in róot (wilt) disease affected tracts, it offers an annual produce 65 nuts/palm. The amount of sensitive nut drinking water is $290 \mathrm{ml}$. That is introduced as an assortment for ténder nut and for farming in root (wilt) common regions of Kerala.

\section{$>\quad$ ChowghatOrangeDwarf(COD)}

This really is an early on blooming cultivar and requires regarding 3-4 years for preliminary flowering. The common annual yield is 63 nuts/palm/year. It's best fitted to young nut drinking water. This conservar premiered simply by CPCRl 20 years ago for huge level farming as sore nut range.

\section{KalpaSree}

Kalpasree has excellent quality of coconut essential oil, very nice tender nut drinking water and meat and is certainly resists róot (wilt) disease. This is actually the earliest blooming cultivar and requires on the subject of 2 . some to three years for its heyday. It really is determined to become resistant to róot (wilt) disease. Thé mean annual yieId is normally 95 nuts/palm using a copra content material of ninety six. 3g. This kind of range is normally released designed for róot (wilt) prevalent regions of Kerala.

\section{$>\quad$ KalpaJyothi}

Little variety with yellowish vegetables, higher typical yield of 114 nut products per hand each year below rained circumstances with approximated copra get of more than 16 kilogram per hands each year. Suggested for cultivation in Kerala and Karnataka for tender nut goal. 


\section{$>$ KalpaSurya}

Little with Citrus fruits suggested for cultivation in Kerala, Karnataka and Tamil Nadu for tender nut goal. The common give is definitely 123 nuts every palm each year under irrigated circumstances with approximated copra out change of $5 \mathrm{~kg}$ every palm each year.

\section{IMPORTANT PROBLEMS OF COCONUT CULTIVATION}

\section{Attack of Pests and Diseases:}

The drop of control keys, premature nuts is because of infection of female bouquets by virus PhytópHthorq spp. Shedding of control keys was found to become principally because of the assault of moth, beetIe and rats.

\section{Nutritional Deficiency:}

Health insufficiency in soil in accountable for- shedding of control keys. Manures application escalates the production of female plants rather than simply by decrease in burning off of switches.

\section{Unfavourable Soil and Climatic Conditions:}

Switch shedding develops because of debt of dampness as because of extra wetting. Relating to Pate] (1938), the shedding of buttons was high during August/September and somewhat lessen during various other weeks, burning off of control keys is more serious on weighty soils thari on ideal soils.

\section{Defective Pollination and Fertilization:}

Not perfect pollination or perhaps insufficient pollination is known as to make a difference point of switch shedding. Man-made pollination didn't minimize burning off.

\section{Formation of Absdission Layer}

When the upsurge in shedding of control keys followed a period an interval of drought, it had been experienced that formula of abscission coating in the area of attachment tó stalk end.

To check on or perhaps minimize the switch burning off $\mathrm{m}$ coconut spraying of two, 4-D for 60 ppm focus by every week length on feminine plants following fertilization designed for per month showed very helpful and resulted, in. a lot more than double leg the environment of switches when compared with those of the neglected inflorescence and increased the yield of nuts.

\section{REVIEW OF LITERATURE}

H. Rajkumar ánd R. Thamil SeIvan (2005) exposed away the importance of coconut like a way to obtain ready-to-eat essential oil so that as an agro-based raw materials for most sectors such as produce of covering powder, and handicrafts. 50 percent of the full total coconut creation is changed into copra. Coconut crop is usually elevated in India under varying ground and weather circumstances in 17 says and a few Union Areas. Therefore the coconut woods is usually versatile in its versatility to wide variety of dirt circumstances, coconut cultivation offers started to spread from the western coastline of India to interior parts of Tamil Nadu specifically to Erode Area and Thanjavur District. Within a comprehensive research of coconut advancement in India, records the various phases of coconut advancement.

Sivarajah and Pónniah (2010) noticed the objective of this kind of study is usually to build up a multi- marketplace model intended for the evaluation of an alternative solution policy choices to improve export products of coconut items coming from Sri Lanka. The extra data around the creation and exports of coconut items are used. Ruse show that depreciation of the rupee exchange price has a significant effect on move prices, level of exports and income of market stakeholders, but there is absolutely no significant effect on the maker prices or perhaps maker earnings, and offer of coconut items. Depreciation of the rupee could improve the income of exporters and the federal government taxes revenue, that could be used to get buying progress fresh technology or factory modernization security schemes. Improved export rates may also increase processing of coconuts and motivate companies to foreign trade even more coconut products. However the depreciation from the rupee offers bigger implications on the overall economy all together, therefore it isn't an affordable policy substitute for choose for the long term.

M. Sajane, H. Basavaraja, S. H. Guledgudda, W. L. Patil, S. M. Mahajanshetty And A. L. S. Bhat (2011), within their research titled "Economic analysis of coconut cultivation" evaluate the growth in the amount of coconut cultivation users, to investigate price of credit rating and the adequacy of credit rating offered below coconut farming in comparison to credit rating without kisan credit cards. The study utilized secondary info on coconut cultivation released and sum sanctioned that was collected by District Business lead Banks along with main data associated with borrowing, curiosity and price of credit etc . via randomly chosen 60 coconut cultivation and 60 non- coconut farming sample agrologist. The info pertained to the harvest 12 months 2008-09. The development of coconut cultivation users in the Belgaum district was unfavorable (-393. $38 \%)$ and alternatively, in Sangli district, the development was positive (36. $18 \%$ ). The full total price of credit rating as ratio of lent quantity was higher inside the non- coconut cultivation category (11. summer \%) when compared with that inside the coconut fostering (4. seventy seven \%). It had been also obvious that the credit rating distributed by the banks pertaining to meals plants (jowar and paddy) was less in comparison with that meant for money vegetation (potato, sugars cane and soybean).

\section{STATEMENT OF THE PROBLEM}

Coconut trees had been a prime source of income of many families in Meenakshipuram Village, Kerala for long, but the situation has changed drastically in recent years. Scarcity of skilled labour and pest attacks has dealt a hard blow to the prospects of the crop.

Escalating labour cost has been one of the major factors that uprooted the confidence of the coconut farmer. Many farmers turned away from coconut farming and several among them switched over to rubber, Professions etc., lured

Published By:

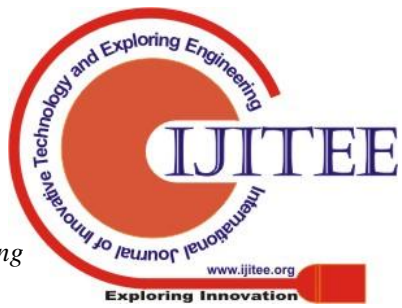


by the handsome prices it fetched. The prices of coconut in various markets also indicate a disadvantage to the Kerala farmer. The coir industry, closely linked with the coconutbased agri-business, has also recorded higher exports, but the problems faced by the former remains a cause for concern. Migration of labour to other areas such as construction industry has weakened the position of the coir sector. In this context it is very interesting to identify the challenges faced by the farmers

\section{OBJECTIVES OF THE STUDY}

- To identify the coconut scenario in
Meenakshipuram Village
- To analyse the agriculturist challenge towards
Coconut cultivation with special reference to
Meenakshipuram Village, Chittur Taluk, Kerala.

\section{RESEARCH METHODOLOGY}

Karupputhuraikadu, a very small fertile village in Meenakshipuram situated nearest border of Tamilnadu but in Chittur Taluk, Kerala, is famous for Sree Ramar Temple, Moolathora dam, Sarkarpathy dam, a famous successful milk cooperative society facilitated by milk producers, toddy production, paddy cultivation, sugarcane cultivation, famous in banana trees, soils are watered by various rivers connected together are specialty of Karupputhuraikadu village. Meenakshipuram, connected its north to Gopalapuram, west to Palakkad and south to Anaimalai and east to Pollachi, is the study area selected for this research. Primary data is collected through well-structured questionnaire. Samples of 100 respondents have already been selected through the use of purposive sample technique. The collected info were examined and consolidated right into a grasp table. For the intended purpose of analysis the info were even more processed through the use of statistical equipment. The statistical tools are

$\checkmark \quad$ Simple Percentage

$\checkmark \quad$ Chi-Square Test

$\checkmark \quad$ Friedman Ranking Method

\section{LIMITATIONS OF THE STUDY}

- $\quad$ The study is fixed to the chosen sample of over town and therefore the consequence of the analysis can not be generalized

- The statistical strategies used to evaluate the info get their own restriction

- All the restrictions of primary info can be applied for this study

\section{ANALYSIS AND INTERPRETATION RESULTS}

\subsection{Demographic Profile of the Agriculturist}

Table no.1 talks about the démographic profile of thé sharecropper for the analysis. Out of 100 participants who were used for the analysis: it's been revealed that a lot of $(63 \%)$ of the surveys takers are natural male, $(57 \%)$ in whose generation is normally under 18 to 5 decades, most $(68 \%)$ of the participants are teachers, the annual rent of (42\%) respondents is normally above Rs. 2, 70, 000, (54\%) of the tree farmer possess two to 12 acres park region for his or her agriculture, $(52 \%)$ of the participants have over a decade harvesting encounter, (64\%) of the participants participate in joint family.

\begin{tabular}{|c|c|c|}
\hline Factors & Number Of Respondents $\mathrm{N}=100$ & Percentage \\
\hline \multicolumn{3}{|c|}{ Gender } \\
\hline Male & 63 & 63 \\
\hline Female & 37 & 37 \\
\hline \multicolumn{3}{|c|}{ Age (Years) } \\
\hline Up to 25 & 14 & 14 \\
\hline 26 to 50 & 57 & 57 \\
\hline Above 50 & 29 & 29 \\
\hline \multicolumn{3}{|c|}{ Educational Qualification } \\
\hline Up to School Level & 68 & 68 \\
\hline Graduate & 21 & 21 \\
\hline Post Graduate & 11 & 11 \\
\hline \multicolumn{3}{|c|}{ Annual Income } \\
\hline Up to Rs. $1,00,000$ & 24 & 24 \\
\hline Rs. $1,00,001$ to Rs. $2,50,000$ & 34 & 34 \\
\hline Above Rs.2,50,000 & 42 & 42 \\
\hline \multicolumn{3}{|c|}{ Farm size (acres) } \\
\hline Up to 2 & 27 & 27 \\
\hline 2 to 10 & 54 & 54 \\
\hline Above 10 & 19 & 19 \\
\hline
\end{tabular}




\begin{tabular}{|l|l|l|}
\hline \multicolumn{3}{|c|}{ Farming experience (years) } \\
\hline Up to 2 Years & 33 & 33 \\
\hline 2 to 10 Years & 25 & 25 \\
\hline Above 10 Years & $52 \quad$ Type of Family & 52 \\
\hline \multicolumn{2}{|c|}{36} \\
\hline Nuclear Family & $36 \quad 64$ \\
\hline Joint Family & 64 & \\
\hline & & 64 \\
\hline
\end{tabular}

Table No.2 Relationship Between Agriculturist Demographic Profile and Level Of Challenge Faced by the Coconut Cultivation

\begin{tabular}{|c|c|c|c|c|c|c|c|}
\hline \multirow[t]{2}{*}{ Variables } & \multicolumn{3}{|c|}{ Level of Challenge } & \multirow[t]{2}{*}{ Total } & \multirow{2}{*}{$\begin{array}{l}\chi^{2} \\
\text { Value }\end{array}$} & \multirow{2}{*}{$\begin{array}{l}\text { Table } \\
\text { Value }\end{array}$} & \multirow[t]{2}{*}{ Remarks } \\
\hline & Low & Moderate & High & & & & \\
\hline \multicolumn{8}{|c|}{ Gender } \\
\hline Male & 13 & 22 & 38 & 63 & \multirow[t]{2}{*}{7.634} & \multirow[t]{2}{*}{5.991} & \multirow[t]{2}{*}{$\mathrm{S}$} \\
\hline Female & 8 & 13 & 16 & 37 & & & \\
\hline \multicolumn{8}{|c|}{ Age (Years) } \\
\hline Up to 25 & 4 & 5 & 5 & 14 & \multirow[t]{3}{*}{12.499} & \multirow[t]{3}{*}{9.488} & \multirow[t]{3}{*}{$\mathrm{S}$} \\
\hline 26 to 50 & 17 & 26 & 14 & 57 & & & \\
\hline Above 50 & 12 & 5 & 12 & 29 & & & \\
\hline \multicolumn{8}{|c|}{ Educational Qualification } \\
\hline Up to School Level & 26 & 20 & 22 & 68 & \multirow[t]{3}{*}{16.178} & \multirow[t]{3}{*}{9.488} & \multirow[t]{3}{*}{$\mathrm{S}$} \\
\hline Graduate & 8 & 8 & 5 & 21 & & & \\
\hline Post Graduate & 4 & 3 & 4 & 11 & & & \\
\hline \multicolumn{8}{|c|}{ Annual Income } \\
\hline Up to Rs. $1,00,000$ & 11 & 7 & 6 & 24 & \multirow[t]{3}{*}{11.823} & \multirow[t]{3}{*}{9.488} & \multirow[t]{3}{*}{$\mathrm{S}$} \\
\hline $\begin{array}{ll}\text { Rs. } 1,00,001 & \text { to } \\
\text { Rs. } 2,50,000\end{array}$ & 9 & 19 & 6 & 34 & & & \\
\hline Above Rs.2,50,000 & 14 & 18 & 10 & 42 & & & \\
\hline \multicolumn{8}{|c|}{ Farm size (acres) } \\
\hline Up to 2 & 12 & 8 & 7 & 27 & \multirow{3}{*}{12.613} & \multirow{3}{*}{9.488} & \multirow{3}{*}{$S$} \\
\hline 2 to 10 & 19 & 23 & 12 & 54 & & & \\
\hline Above 10 & 4 & 9 & 6 & 19 & & & \\
\hline \multicolumn{8}{|c|}{ Farming experience (years) } \\
\hline Up to 2 Years & 12 & 9 & 6 & 33 & \multirow{3}{*}{12.543} & \multirow{3}{*}{9.488} & \multirow{3}{*}{$S$} \\
\hline 2 to 10 Years & 15 & 21 & 18 & 25 & & & \\
\hline Above 10 Years & 8 & 6 & 5 & 52 & & & \\
\hline \multicolumn{8}{|c|}{ Type of Family } \\
\hline Nuclear Family & 7 & 20 & 9 & 36 & 0 & & \\
\hline Joint Family & 18 & 34 & 12 & 64 & 3.598 & 5.991 & $\mathrm{~S}$ \\
\hline
\end{tabular}


1.2. Relationship between the Demographic Profile and level of challenge towards coconut cultivation

Table no. 2 describes the partnership among determined massive variables and Degree of the task of the participants. It really is obvious that, the calculated Chi-square value is without question higher than the table worth at five percent level, there is present any significant association among gender, age group, annual income, gender, educational course, farm size, farming experience, kind of category of the dirt farmer and degree of challenge confronted by the agriculturist towards coconut cultivation.

Table No.5

Agriculturist Challenges- Friedman Rank Test

\begin{tabular}{|l|l|l|}
\hline Problem & $\begin{array}{l}\text { AVERAGE } \\
\text { RANK }\end{array}$ & RANK \\
\hline Lack of Motivation & 3.7 & 4 \\
\hline Import & 2.8 & 5 \\
\hline Unstable Price & 6.8 & 1 \\
\hline Climatic factors cost of & 5.2 & 3 \\
\hline $\begin{array}{l}\text { High } \\
\text { Cultivation }\end{array}$ & 2 \\
\hline Mixed Farming & 1.7 & 6 \\
\hline Pecticides/Preservatives & 1.2 & 7 \\
\hline
\end{tabular}

The above table shows about the Friedman Rank Test challenges faced by the agriculturist towards coconut cultivation were the level of significance is at 0.000 which will shows that there exists a relationship between their ranks offered. The challenges faced by the agriculturist towards coconut cultivation through Friedman rank test, it is found that majority of the agriculturist problem are unstable price in the market, high cost of cultivation, climatic factors, lack of motivation, import, mixed farming and preservatives. Thus, it found from the above table that most of the agriculturist problem towards coconut cultivation is unstable price in the market.

\section{CONCLUSION}

Coconut sector is usually facing a whole lot of complications more recently. To begin with, agriculturist don't get the proper value for coconut. However in elegant area it really is sold for a lot more than $3 \mathrm{x}$ regarding the purchase price growers get. Therefore the intermediary people consider the benefit. This could be solved to an excellent broaden by effectively using the Coconut Manufacturers' Societies (CPS). Eách CPS after collecting the coconuts fróm growers can sell them by urbán region. Hence the customér's burden of paying out high cost to coconut could be lowered to an excellent extend. The same manner CPS are certain to get a lot of profit that will ultimately visit the agriculturist simply.

\section{REFERENCES}

1. Raj Kumar S. and Thamilselvan, R. "Importance of Coconut Cultivation", Kisan World, Vol. 32, No. 5, May 2005, p. 58. International Journal of Engineering Research and Modern Education (IJERME) ISSN (Online): 2455 - 4200 (www.rdmodernresearch.com) Volume I, Issue II, 2016

2. Sivarajah and Ponniah, 2010, "IUP Journal of Applied Economics”, Vol. 9 Issue 3, pp 97- 113.

\section{ABOUT AUTHOR AND ARTICLE}

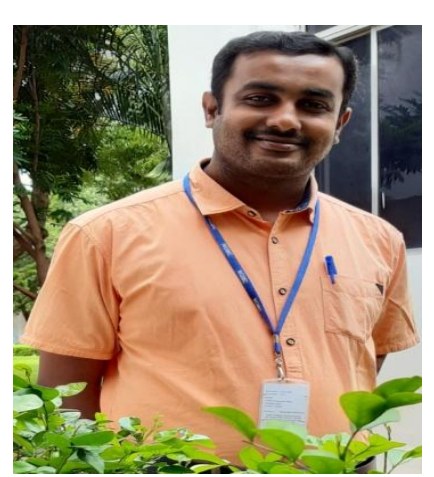

Dr.K.Veerakumar - from a small village called Karupputhuraikadu, situated in Meenakshipuram in Chittur taluk of Pallakad District, Kerala is basically from a very poor agriculturist family migrated from Tamilnadu two generations back due to destitution. Completed secondary Schoolings in Sree Krishna Vidhyalayam Matric Higher Secondary School, Valanthayamaram and Higher Secondary Education in Palaniammal Higher Secondary School, V.Kaliyapuram and Under Graduate, Post Graduate, Diploma and Research Programmes in Nallamuthu Gounder Mahalingam College, Pollachi, few more degrees in various other Universities too, has shown interest in agriculture but sound education helped to become educationalist. In young age, published many articles in reputed journals with highly appreciable impact factor, the research topics says how trendy and fast, Researches are... Also awarded with various numbers of awards in Academic life and honored and appreciated by famous personalities and organizations, outstanding performance in teaching created many successful students to various positions and now considers them as assets. Interest shown in Educational, Academic and Research life made him as Head of the Department at present. 